\title{
Performance of Soybean Varieties in Response to Varied Sowing Dates under the Sub-Montane Climatic Conditions of Maharashtra, India
}

\author{
R. D. Nigade* and P. N. Gajbhiye \\ Zonal Agricultural Research Station, Shenda Park, Kolhapur-416 012, (M.S), India \\ *Corresponding author
}

\begin{abstract}
A B S T R A C T
Rainfall distribution is most adversely affected due to change in climatic conditions. Considering 26 years of rainfall data, rainfall characterization of Kolhapur region advocated that the best suited sowing dates for kharif crops is $23^{\text {rd }} \mathrm{MW}$ and $24^{\text {th }} \mathrm{MW}$. The recent anomalies in onset and withdrawal of monsoon emerged with a need to develop an advisory for growers regarding sowing of soybean crop in particular. An experiment was therefore conducted with four sowing dates i.e. $23^{\text {rd }}$ MW, $25^{\text {th }}$ MW, $27^{\text {th }}$ MW and $29^{\text {th }}$ MW and four varieties such as Phule Agrni, Phule Kalyani, KS 103 and JS 335 tested in split plot design with three replications. This experiment was carried out at the Zonal Agricultural Research Station, Shenda Park, Kolhapur(Maharashtra) during kharif seasons for three consecutive years to study effect of different sowing dates on growth, yield and quality of soybean cultivars under rainfed conditions. The periodical growth observations and yield contributing characters were recorded as per the schedule. The results of this study revealed that the first sowing date of $23^{\text {rd }}$ MW exhibited significantly highest number of pods per plant (40.04), test weigh (19.74) and grain yield of soybean (20.32 $\left.\mathrm{q} \mathrm{ha}^{-1}\right)$ however, the second sowing date of $25^{\text {th }}$ MW found to be closely and equally suited for kharif sowing of soybean crop. Delayed sowing of soybean revealed decline in yield irrespective of varieties tested. Among the varieties, Phule Agrani, recorded significantly highest number of pods per plant (39.59), test weigh (21.74), grain and straw yield of soybean 19.77 and $21.08 \mathrm{q} \mathrm{ha}^{-1}$ respectively. The interaction between sowing dates and varieties were found to be statistically insignificant.
\end{abstract}

\section{Introduction}

Oilseed crops have been the backbone of country economy from time immemorial. Soybean (Glycine max L.) stands first in the world as edible oil and occupies important place in the economy. Globally legumes play a vital role in human nutrition as these are rich sources of protein, calories, certain minerals and vitamins. Among legumes, soybean is the largest source of protein and vegetable oil with poly-unsaturated fatty acids specially Omega 6 and Omega 3 (Chauhan et al., 1988). Soybean is cultivated on 124 million ha area in the world. India ranks $5^{\text {th }}$ in area and production after USA, Brazil, China and Argentina while, Maharashtra stands $3^{\text {rd }}$ after Rajasthan and Madhya Pradesh (Anonymous, SOPA 2019).

It is most admired crop under the oil seed category probably due to the fact that even under minimum agricultural inputs and management practices it fetches profitable 
returns to the growers. In recent years soybean has assumed position in India as it is one of the most stable kharif crops yielding cost effective production in varied agroclimatic conditions (Kumar et al., 2008). It contributes nearly 25 per cent of the world's total oil and fat production. India has made impressive progress in agriculture during the last three decades, culminating in selfsufficiency in cereals and made good efforts in increasing the production and productivity of pulses and oilseeds crops. Sowing date play a vital role in crop production, sowing too early or too late may decrease the yield and quality of crop due to insect, disease and weed pressure apart from these factors soil moisture availability and temperature also has significant part to play in crop production (Shah and Hatom, 2009). In the changing climatic scenario, rainfall distribution is most adversely affected resulting in erratic rainfall pattern. Based on 26 years rainfall data of Kolhapur region, for rainfed cropping system to ensure maximum utilization of moisture and increased production in Kharif season sowing during $23^{\text {rd }}$ and $24^{\text {th }} \mathrm{MW}$ is best suited. In $23^{\text {rd }} \mathrm{MW}$ the rainfall probability is more than $50 \%$ however, dry sowing is mostly advocated during $22^{\text {nd }} \mathrm{MW}$ for the region.

The period from $36^{\text {th }}$ to $38^{\text {th }} \mathrm{MW}$ is characterized by occurrence of one or two dry spell (Chunale and Bansode 2002). Despite, there are abnormalities in onset and withdrawal of monsoon which has emerged as a major challenge for growers. There is a need to establish a fine-tune with the environment for more economical and sustainable crop yield. Sowing date management is absolutely no cost practice that can ensure better crop production and crop-environment interaction in the changing climatic conditions. Soybean is known for its versatility to be grown in diverse climatic conditions and for its unmatched nutritional value, which makes it one of the important commercial crops in many countries including India. Different varieties of soybean are sensitive to change in environmental conditions (Calvino et al., 2003). In this context, there are meagre guidelines for the soybean producing growers. The objective is to determine sowing dates that would provide an optimum growing period, maximum utilization of soil available water and enhancement in crop yield. An attempt was therefore made to study the impact of sowing dates on yield of different soybean cultivars in the sub-montane zone of Maharashtra.

\section{Materials and Methods}

The present investigation was conducted for the period of three years during kharif 20152017 seasons at Zonal Agricultural Research Station, Sub-montane Zone, Kolhapur (Maharashtra) situated atlatitude of $16^{\circ} 43^{\prime} \mathrm{N}$, longitude $74^{\circ} 14^{\prime} \mathrm{E}$ and altitude $574 \mathrm{~m}$ above mean sea level representing the sub-montane zone of Maharashtra. The experiment site was silty loam with $\mathrm{pH}-7.20$, E.C.- $0.15 \mathrm{dSm}^{-1}$, organic carbon 0.48 per cent and belongs to order Entisols. The initial soil test values revealed low status of available nitrogen (198. $\left.\mathrm{kg} \mathrm{ha}^{-1}\right)$, medium $\mathrm{P}\left(10.3 \mathrm{~kg} \mathrm{ha}^{-1}\right)$ and low in $\mathrm{K}\left(145 \mathrm{~kg} \mathrm{ha}^{-1}\right)$. The total annual rainfall received during 2015, 2016 and 2017 was $714 \mathrm{~mm}$ in 57 days, $1067.6 \mathrm{~mm}$ in 59 rainy days and $972.2 \mathrm{~mm}$ in 70 rainy days respectively. The region experiences dry spell during grand growth phase i.e. 33 to $35 \mathrm{MW}$ which adversely affect the yield of crop (Chunale and Bansode 2002).By taking basis of 26 years rainfall characterization data into account, four sowing dates were considered such as $23^{\text {rd }} \mathrm{MW}, 25^{\text {th }} \mathrm{MW}, 27^{\text {th }} \mathrm{MW}$ and $29^{\text {th }}$ MW and four prominent varieties viz. Phule Agrani, Phule Kalyani, KS 103 and JS 335 were tested in this study. The present experiment was laid out in split design and combination treatments were replicated thrice. 
The gross plot size was $4.00 \times 3.6 \mathrm{~m}^{2}$ and net plot of size $3.60 \times 2.70 \mathrm{~m}^{2}$ was harvested for final data computation. Seed rate of $75 \mathrm{~kg} \mathrm{ha}^{-1}$ was used for sowing at spacing $30 \mathrm{~cm} \times 10$ $\mathrm{cm}$ in all treatments. The soybean crop was fertilized with recommended dose of fertilizer i.e. $50 \mathrm{~kg} \mathrm{ha}^{-1} \mathrm{~N}, 75 \mathrm{~kg} \mathrm{ha}^{-1} \mathrm{P}_{2} 0_{5}$ through urea and single super phosphate respectively. The tabulated data were statistically processed by standard method of analysis of variance for the split plot design and test of significance as given by Panse and Sukhatme (1985).

\section{Results and Discussion}

\section{Yield attributes}

The pooled data presented in table 1 indicated that the significantly highest number of pods per plant (40.04) was observed with first sowing date i.e. on $23^{\text {rd }} \mathrm{MW}$ over all other sowing dates however, it was found to be at par with $25^{\text {th }}$ MW (39.55). In context of test weight, significant highest 100 seed weight (19.74 gm) was recorded at first sowing date i.e. on $23^{\text {rd }} \mathrm{MW}$ over all other sowing dates while it was at par with second sowing date i.e. on $25^{\text {th }}$ MW (19.54 gm). Amongst the various tested varieties, Phule Agrani recorded significantly highest number of pods per plant of soybean (39.59) and test weigh (21.74) as compared to all other varieties. The interaction effects between sowing dates and varieties were found to be statistically nonsignificant.

Early sowing at $23^{\text {rd }}$ to $25^{\text {th }} \mathrm{MW}$ was found to be the most appropriate sowing time under Sub-montane zone condition as there is continuous rains from $25^{\text {th }} \mathrm{MW}$ onwards for getting higher number of pods and test weight across years and varieties. This could be because delayed planting date and unfavorable environmental conditions have a negative effect on soybean growth, development, and yield. Changes in photoperiod, temperature, and precipitation with delayed planting affect the duration of vegetative and reproductive stages, number of branches and pods, plant height, leaf area index (LAI), and normalized difference vegetation index (NDVI), and hence the grain yield (Hu and Wiatrak2012). Similar results were also reported by Youngkil et al., (1998), Bhatia et al., (1999) and Nishioka and Okumura (2008)

\section{Grain and straw yield}

Soybean grain and straw yield revealed similar pattern to that of growth attributes as it is very obvious that better growth contributes towards better yield. The pooled data presented in table 2, revealed that the first sowing date i.e. on $23^{\text {rd }}$ week MW recorded highest grain yield of soybean $\left(20.32 \mathrm{q} \mathrm{ha}^{-1}\right)$ which was at par with second sowing date i.e. on $25^{\text {th }} \mathrm{MW}\left(20.08 \mathrm{q} \mathrm{ha}^{-1}\right)$ and third sowing date i.e. $27^{\text {th }}$ MW (17.03 q $\mathrm{ha}^{-1}$ ) and significantly superior over sowing at $29^{\text {th }}$ MW $\left(13.41 \mathrm{q} \mathrm{ha}^{-1}\right)$. In case of straw yield significantly highest straw yield of soybean $\left(21.25 \mathrm{q} \mathrm{ha}^{-1}\right)$ was recorded with second sowing date i.e. on $25^{\text {th }} \mathrm{MW}$ over sowing done on $29^{\text {th }}$ MW. However, it was at par with sowing done on $23^{\text {rd }}$ and $27^{\text {th }}$ MW. The various varieties tested differed significantly in terms of grain and straw yield.

The highest grain and straw yield of soybean $\left(19.77 \& 21.08 \mathrm{q} \mathrm{ha}^{-1}\right)$ respectively was recorded with the variety Phule Agrani, which was significantly superior over all the varieties. In context of yields the interaction between sowing dates and varieties were found to be statistically non-significant. In general, it was observed that delayed sowing of soybean has undesirable effect on grain yield. The sowing date beyond $25 \mathrm{MW}$ i.e at $27^{\text {th }}$ MW and $29^{\text {th }}$ MW revealed yield reduction of 16.11 , and $43.31 \%$, respectively. 
Table.1 Growth attributes of soybean as influenced by different treatments (pooled values)

\begin{tabular}{|c|c|c|c|c|c|c|c|c|}
\hline \multirow[t]{2}{*}{ Treatments } & \multicolumn{4}{|c|}{ No. of pods plant ${ }^{-1}$} & \multicolumn{4}{|c|}{100 grain weight (gm) } \\
\hline & $\begin{array}{c}2015- \\
16\end{array}$ & $\begin{array}{c}2016- \\
17\end{array}$ & $\begin{array}{c}2017- \\
18\end{array}$ & $\begin{array}{c}\text { Pooled } \\
\text { Mean }\end{array}$ & $2015-16$ & $\begin{array}{c}\text { 2016- } \\
17\end{array}$ & $2017-18$ & $\begin{array}{c}\text { Pooled } \\
\text { Mean }\end{array}$ \\
\hline \multicolumn{9}{|l|}{ A. Sowing dates (4) } \\
\hline$D_{1}-23^{\text {rd }} M W$ & 31.87 & 43.12 & 44.96 & 40.04 & 19.25 & 20.61 & 19.35 & 19.74 \\
\hline $\mathrm{D}_{2}-25^{\text {th }} \mathrm{MW}$ & 26.90 & 45.12 & 46.62 & 39.55 & 18.58 & 19.74 & 20.29 & 19.54 \\
\hline $\mathrm{D}_{3}-27^{\text {th }} \mathrm{MW}$ & 17.50 & 34.32 & 34.82 & 28.88 & 18.17 & 19.16 & 19.32 & 18.88 \\
\hline$D_{4}-29^{\text {th }} M W$ & 17.34 & 32.62 & 32.95 & 27.13 & 17.67 & 17.61 & 18.24 & 17.92 \\
\hline S.E. \pm & 0.97 & 1.14 & 1.23 & 1.048 & 0.29 & 0.14 & 0.15 & 0.31 \\
\hline C.D. 0.05 & 3.36 & 3.93 & 4.25 & 3.63 & 0.99 & 0.48 & 0.53 & 1.07 \\
\hline \multicolumn{9}{|l|}{ B. Varieties (4) } \\
\hline$V_{1}-$ PhuleAgrani & 30.70 & 43.33 & 44.75 & 39.59 & 21.17 & 22.00 & 22.05 & 21.74 \\
\hline$V_{2}-$ PhuleKalyani & 23.58 & 37.33 & 39.25 & 33.30 & 18.75 & 20.02 & 19.73 & 19.58 \\
\hline$V_{3}-K S 103$ & 20.11 & 39.97 & 40.30 & 33.26 & 17.83 & 18.66 & 18.83 & 18.44 \\
\hline$V_{4}-J S 335$ & 19.21 & 34.54 & 35.04 & 29.35 & 15.92 & 16.43 & 16.61 & 16.32 \\
\hline S.E. \pm & 1.32 & 1.28 & 1.36 & 0.68 & 0.38 & 0.25 & 0.36 & 0.11 \\
\hline C.D. 0.05 & 3.86 & 3.74 & 3.97 & 1.985 & 1.10 & 0.72 & 1.06 & 0.32 \\
\hline \multicolumn{9}{|l|}{ Interaction } \\
\hline S.E. \pm & 2.64 & 2.56 & 2.72 & 1.36 & 0.76 & 0.50 & 0.72 & 0.22 \\
\hline C.D. 0.05 & NS & NS & NS & NS & NS & NS & NS & NS \\
\hline
\end{tabular}

Table.2 Grain and straw yield of soybean as influenced by different treatments (Pooled values)

\begin{tabular}{|c|c|c|c|c|c|c|c|c|}
\hline \multirow[t]{3}{*}{ Treatments } & \multicolumn{4}{|c|}{ Grain yield } & \multicolumn{4}{|c|}{ Straw yield } \\
\hline & \multicolumn{8}{|c|}{ 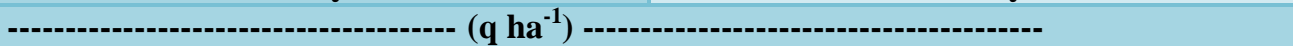 } \\
\hline & $2015-16$ & $\begin{array}{c}2016- \\
17\end{array}$ & $2017-18$ & $\begin{array}{l}\text { Pooled } \\
\text { Mean }\end{array}$ & $2015-16$ & $2016-17$ & $\begin{array}{c}2017- \\
18\end{array}$ & $\begin{array}{l}\text { Pooled } \\
\text { Mean }\end{array}$ \\
\hline \multicolumn{9}{|l|}{ A. Sowing dates (4) } \\
\hline$D_{1}-23^{\text {rd }} M W$ & 13.90 & 23.05 & 23.42 & 20.32 & 15.29 & 24.67 & 23.58 & 21.19 \\
\hline $\mathrm{D}_{2}-25^{\text {th }} \mathrm{MW}$ & 13.94 & 22.19 & 25.09 & 20.08 & 14.37 & 23.74 & 25.61 & 21.25 \\
\hline $\mathrm{D}_{3}-27^{\text {th }} \mathrm{MW}$ & 9.80 & 19.73 & 21.54 & 17.03 & 10.66 & 21.65 & 20.83 & 17.72 \\
\hline $\mathrm{D}_{4}-29^{\text {th }} \mathrm{MW}$ & 8.07 & 12.59 & 13.41 & 11.52 & 8.73 & 12.18 & 13.91 & 11.48 \\
\hline S.E. \pm & 0.70 & 0.82 & 1.77 & 0.99 & 0.92 & 1.03 & 1.13 & 1.09 \\
\hline C.D. 0.05 & 2.43 & 2.84 & 6.12 & 3.45 & 3.17 & 3.56 & 3.90 & 3.77 \\
\hline \multicolumn{9}{|l|}{ B. Varieties (4) } \\
\hline$V_{1}-$ Phule Agrani & 14.23 & 21.33 & 23.71 & 19.77 & 15.76 & 22.57 & 24.87 & 21.07 \\
\hline$V_{2}-$ Phule Kalyani & 11.03 & 19.88 & 20.54 & 17.16 & 12.00 & 21.58 & 20.60 & 18.07 \\
\hline$V_{3}-K S 103$ & 10.55 & 19.73 & 20.66 & 17.28 & 11.47 & 20.30 & 20.35 & 17.25 \\
\hline $\mathbf{V}_{4}-\mathbf{J S} 335$ & 9.89 & 16.62 & 18.54 & 14.74 & 9.81 & 17.79 & 18.11 & 15.25 \\
\hline S.E. \pm & 0.55 & 0.76 & 1.12 & 0.33 & 0.84 & 0.85 & 1.62 & 0.36 \\
\hline C.D. 0.05 & 1.59 & 2.22 & 3.27 & 0.97 & 2.46 & 2.47 & 4.73 & 1.07 \\
\hline \multicolumn{9}{|l|}{ Interaction } \\
\hline S.E. \pm & 1.09 & 1.52 & 2.42 & 0.66 & 1.69 & 1.69 & 3.24 & 0.73 \\
\hline C.D. 0.05 & NS & NS & NS & NS & NS & NS & NS & NS \\
\hline
\end{tabular}


Table.3 Influence of different treatment on economics applied to soybean crop (pooled values)

\begin{tabular}{|c|c|c|c|c|c|c|c|c|c|c|c|c|}
\hline \multirow[t]{3}{*}{ Treatments } & \multicolumn{4}{|c|}{ Gross Monetary Returns } & \multicolumn{4}{|c|}{ Net Monetary Returns } & \multicolumn{4}{|c|}{ B:C Ratio } \\
\hline & \multicolumn{12}{|c|}{--------------------------------( ${ }$} \\
\hline & $\begin{array}{c}2015- \\
16\end{array}$ & $\begin{array}{c}2016- \\
17\end{array}$ & $2017-18$ & $\begin{array}{r}\text { Pooled } \\
\text { Mean }\end{array}$ & $2015-16$ & $\begin{array}{c}2016- \\
17\end{array}$ & $\begin{array}{c}2017- \\
18\end{array}$ & $\begin{array}{l}\text { Pooled } \\
\text { Mean }\end{array}$ & $\begin{array}{c}2015- \\
16\end{array}$ & $\begin{array}{c}2016- \\
17\end{array}$ & $\begin{array}{c}2017- \\
18\end{array}$ & $\begin{array}{l}\text { Pooled } \\
\text { Mean }\end{array}$ \\
\hline \multicolumn{13}{|l|}{ A. Sowing dates (4) } \\
\hline$D_{1-} 2^{\text {rd }} M W$ & 108288 & 116812 & 72006 & 63480 & 57964 & 61842 & 20554 & 18264 & 2.14 & 2.13 & 1.40 & 1.27 \\
\hline $\mathrm{D}_{2}-25^{\text {th }} \mathrm{MW}$ & 120059 & 155105 & 77193 & 64289 & 69569 & 100135 & 25741 & 19857 & 2.38 & 2.82 & 1.50 & 1.29 \\
\hline $\mathrm{D}_{3}-27^{\text {th }} \mathrm{MW}$ & 94480 & 139416 & 66162 & 53706 & 41990 & 84446 & 14710 & 11351 & 1.83 & 2.54 & 1.29 & 1.07 \\
\hline$D_{4}-29^{\text {th }} M W$ & 64582 & 106510 & 41508 & 35703 & 13259 & 51540 & 10193 & -7946 & 1.27 & 1.94 & 0.80 & 0.72 \\
\hline S.E. \pm & 6759 & 5248 & 5233 & 2976 & 7000 & 5248 & 5319 & 3132 & 0.14 & 0.10 & 0.10 & 0.05 \\
\hline C.D. 0.05 & 23294 & 18164 & 18111 & 10299 & 24229 & 18165 & NS & NS & 0.48 & 0.33 & 0.36 & 0.19 \\
\hline \multicolumn{13}{|l|}{ B. Varieties (4) } \\
\hline$V_{1}-$ PhuleAgrani & 113662 & 144003 & 72988 & 62267 & 60038 & 89033 & 21535 & 17895 & 2.19 & 2.62 & 1.42 & 1.25 \\
\hline $\mathbf{V}_{2}-$ Phule Kalyani & 102412 & 134739 & 63392 & 54125 & 51923 & 79769 & 11690 & 10325 & 2.03 & 2.45 & 1.23 & 1.08 \\
\hline$V_{3}-K S 103$ & 90555 & 126759 & 63506 & 53552 & 40065 & 71789 & 12054 & 9620 & 1.79 & 2.31 & 1.24 & 1.07 \\
\hline$V_{4}-$ JS 335 & 81079 & 112342 & 56983 & 47237 & 30755 & 57373 & 5531 & 3685 & 1.61 & 2.04 & 1.11 & 0.95 \\
\hline S.E. \pm & 5158 & 3697 & 3369 & 899 & 5127 & 3697 & 3378 & 1071 & 0.10 & 0.07 & 0.07 & 0.02 \\
\hline C.D. 0.05 & 15054 & 10791 & 9835 & 2625 & 14966 & 10791 & NS & NS & 0.30 & 0.20 & 0.19 & 0.06 \\
\hline \multicolumn{13}{|l|}{ Interaction } \\
\hline S.E. \pm & 10315 & 7394 & 6738 & 1799 & 10255 & 7394 & 6756 & 2141 & 0.20 & 0.13 & 0.13 & 0.04 \\
\hline C.D. 0.05 & NS & NS & NS & NS & NS & NS & NS & NS & NS & NS & NS & NS \\
\hline
\end{tabular}


Soybean being a shortday plant is highly influenced by photoperiod. Date of sowing is an important factor influencing growth and yield of soybean (Bastidas et al., 2008).Delayed sowing reduces yield when compared with earlier sowings (Beatty et al., 1982). Wide variations in productivity parameters among the date of sowing have also been observed by Bhatia et al., 1999; Motta et al., 2000.Shishodia and Sneller, (1996) reported that the average seed yield decreases with delay in sowing date. Billore and Shrivastava (2013) reported that the early planting of soybean increases the seed yield. The similar findings were also reported by Weaver et al., 1991.

\section{Economics}

The data presented in Table 3 revealed that the significantly highest gross monitory returns (Rs. 64289/-) was recorded with second sowing date i.e. on $25^{\text {th }} \mathrm{MW}$ over sowing done on $29^{\text {th }}$ MW however, it was at par with sowing done on $23^{\text {rd }} \mathrm{MW}$ and $27^{\text {th }}$ MW. The net monitory returns (Rs. 25741/-) and B:C (1.29) ratio was highest with second sowing date i.e. on $25^{\text {th }} \mathrm{MW}$.

Comparing among the tested varieties, significantly highest gross monetary returns (Rs.62267/-) was recorded with the variety Phule Agrani however, it was at par with Phule Kalyani and KS 103. The variety Phule Agrani also recorded highest net monitory returns (Rs. 17895/-) and B:C ratio (1.25) as compared to other varieties. Singh et al., (1999) reported that the highest net return and benefit cost ratio of crop was recorded with early sowing and combined application recommended fertilizer + FYM + biofertilizer. It is essential to establish a fine tuning between the agro-climatic conditions and sowing date of soybean. Delayed sowing of soybean could result in decline in growth and yield of soybean.
Sowing of soybean during $23^{\text {rd }}$ to $25^{\text {th }} \mathrm{MW}$ i.e. $2^{\text {nd }}$ to $3^{\text {rd }}$ week of June is found beneficial for getting higher yields and gross monetary returns in case of delayed onset of monsoon in Sub montane climatic condition of Maharashtra while beyond that there is substantial decline in soybean yield.

\section{References}

Anonymous (2019). Area production estimates of soybean in India Kharif. sopa@sopa.org.

Bastidas, A. M., Setiyono, T. D., Dobermann, A., Cassman, K. G., Elmore, R. W., Graef, G. L. and Specht, J. E. (2008). Soybean Sowing Date: The vegetative, reproductive and agronomic impacts. Crop Science. 48: 727-40

Beatty, K. D., Eldridge, I. L. and Simpson, A. M. (1982). Soybean response to different planting patterns and dates. Agronomy Journal. 74: 859-862.

Bhatia, V.S., Tiwari, S.P. and Joshi, O.P. (1999). Yield and its attributes as affected by planting dates in soybean (Glycine max) varieties. The Indian Journal of Agricultural Sciences, 69(10).

Billore, S.D. and Shrivastava, S.K. (2013). Sustainability and stability of yield of soybean varieties under various planting time in different agro climatic regions of India. Soybean

Research, 11(2): 8-16.

Calvino P.A, Sadras V.O. and Andrade F.H. (2003). Quantification of environmental and management effects on the yield of late-sown soybean. Field Crops Research,83: 67-77.

Chauhan, G.S., Verma, N.S. and Basin, G.S. 1988. Effect of extrusion processing on the nutritional quality of protein in rice legume blends. Nahrung32:43-47.

Chunale G.L. and Bansod, R.D. (2002). Rainfall characteristics and rainfall 
based cropping strategies for Kolhapur (M.S). Research on Crops 3(1):181-189

$\mathrm{Hu}$ Mengxuan and Wiatrak Pawel 2012. Effect of Planting Date on Soybean Growth, Yield, and Grain Quality: Review. Agronomy Journal104, (3): 785-790

Kumar, A., Pandey, V., Shekh, A.M. and Kumar, M. (2008). Growth and yield response of soybean (Glycine max L.) in relation to temperature, photoperiod and sunshine duration at Anand, Gujrat India. AmericanEurasian Journal ofAgronomy 1(2):4550.

Motta I. De S. Braccini, A.de L., Scapim, C.A., Goncalves, A.C.A. and Braccini, M. do C.L. (2000). Agronomic traits and yield components of soybean seeds with different sowing dates. Revista Brasileria de Sementes, 22(2): 153-162.

Nishioka, H. and Okumura, T. (2008). Influence of sowing time and nitrogen topdressing at the flowering stage on the yield and pod character of green soybean [Glycine $\max (\mathrm{L}$.$) \quad Merrill].$ Plant Production Science, 11(4): 507513.
Shah, Zahir and M.R. Hatom, (2009). Effect of planting dates on the yield and yield component of determinate and indeterminate soybean cultivars. Sarhad J. Agril., 5: 56-67.

Shishodia, S.K. and Singh, S.S. (1995). Effect of different planting dates on growth parameters, yield and quality components of three soybean cultivars. Indian Journal of Environment and Toxicology, 5(2):77-79.

Singh, Kulvir, Singh, Sarbjeet and Kler, D.S. (1999). Effect of sowing dates, densities and plant rectangularities on growth and seed yield of soybean [Glycine $\max$ (L.) Merril]. Environment and Ecology, 17(2): 436-443.

Weaver, D.B., Akridge, R.L. and Thomas, C.A. (1991). Growth habit, planting date and row spacing effects on lateplanted soybean. Crop Science, 31(3): 805-810.

Youngkil, Kang, Cho, KoMiRa and Yang Mum, Namki Park (1998). Effect of planting date and planting density on growth and yield of soybean in Cheju island. Korean Journal of Crop Science. 43(1): 44-48.

\section{How to cite this article:}

Nigade. R. D. and Gajbhiye. P. N. 2020. Performance of Soybean Varieties in Response to Varied Sowing Dates under the Sub-Montane Climatic Conditions of Maharashtra, India. Int.J.Curr.Microbiol.App.Sci. 9(06): 1726-1732. doi: https://doi.org/10.20546/ijcmas.2020.906.214 